\title{
BETWEEN HUMAN RIGHTS AND JUSTICE PRINCIPLE IN CHILDREN'S CIVIL RIGHTS
}

\author{
Wurianalya Maria Novenanty ${ }^{1}$ Faculty of Law \\ Parahyangan Catholic University \\ Bandung, Indonesia
}

\begin{abstract}
:
Children's rights are fundamental in a country. Children are the future generation of a country. They have rights in civil law field. The examples of such rights are the right to have family name, the right to get alimony, and the right to get inheritance from the parents. Indonesian Law Number 1 of 1974 regarding Marriage (Marriage Law) distinguishes the civil rights of legitimate and illegitimate children. In 2010, the Indonesian Constitutional Court produced a decision which became a controversial decision because it was deemed to 'legalize' illegitimate child to have the same rights as legitimate child. The reason behind such decision is the human rights which should apply nondiscriminative principle. Some parties disagree with the reasoning behind this decision. They consider the decision unjust and that it violates social and religious norms in giving illegitimate and legitimate children the same rights in spite of the status difference. The author will discuss children's civil rights based on civil law, human rights, and justice principle in Indonesia.
\end{abstract}

Keywords:

child • civil law • marriage law $\bullet$ civil rights $\bullet$ human rights $\bullet$ justice principle - constitutional court

\section{Introduction}

There has been a saying "a child is a gift from God". That is why parents must take good care of their children because God entrusts them to the parents. In civil law, human is a legal subject, including a child. A child carries rights and obligations as a legal subject. Children reserve their rights to be taken care of and educated by their parents, the rights which 
are the parents' obligations as regulated in Article 45 (1) Law Number 1 of 1974 regarding Marriage. Yet, the Law regulates that there are differences between the rights for the children who are born in wedlock and the children who are born out of the wedlock. A child who is born in wedlock is qualified as a legitimate child. Hence, the child has full rights from the father and mother in the civil law. On the other side, a child who is born out of wedlock is qualified as an illegitimate child. Such child will only have a legal bound with his/her mother, or in the other words the child has no legal bound with his/her father. The term of legal bound in private law means there are obligations which have to be fulfilled by the parent to his/her descendants, including obligations to grant a family name, to raise, to educate, to have them inherit the wealth, and to support them not only mentally, but also financially. The difference between the civil rights of legitimate child and illegitimate child can be reviewed from three aspects which are civil law, human rights law, and justice principle. I would like to review such difference from these aspects.

\section{Children's Civil Rights According to the Civil Law}

Initially, the child's rights in private law are regulated in the Civil Code, which is a code established by the Dutch colonial government. ${ }^{2}$ Most of the substance and form are similar to the France Civil Code, and even according to J. Van Kan, Dutch Civil Code is a paraphrase of France Civil Code. ${ }^{3}$ The Dutch Civil Code still prevailed after the independence of Indonesia based on the article 2 of transitional provisions of Indonesia Constitution. ${ }^{4}$

Child's rights in the Civil Code are categorized by the child's status, whether he/she is a legitimate child or a child outside of wedlock. ${ }^{5}$ There are three types of an out of wedlock child: ${ }^{6}$

1. A child who is born of a father and a mother, yet between them there is no prohibition to get married. The child status will be the same as a legitimate child, in the event that the parents get married, or the child will be recognized if the parents are unmarried (Article 272 of Civil Code).

2. A child who is born of a man and a woman, who each other has a closed blood relation or there is a relation caused by 
marriage bound (Article 30 and 31 of Civil Code). A child who is born of an incest relation is called "incest child". The child cannot be legalized or recognized, unless there is permission from the President or the Justice Minister (Article 31 juncto Article 273 Civil Code).

3. A child who is born of a man and a woman, who is forbidden to get married according to the Law, or one of the party or both are in a marriage bound with another person. This child is called an illegitimate child.

In the Law Number 1 of 1974 regarding Marriage, the child's status is stipulated in Article 42 to Article 44. The definition of a legitimate child in the Law is a child who is born in or as a result of a legitimate marriage. ${ }^{7}$ Moreover, the provisions regarding an illegitimate child are found in Article 43:8

(1) "A child who is born out of wedlock has a civil relationship with his/her mother and the mother's family.

(2) The child's status as stipulated on paragraph (1) furthermore will be regulated in the government regulation."

Determining whether a child is legitimate or illegitimate is also a fulfillment of the administration procedure which is regulated by the citizenship administration law. If the parents do not get married or they get married but such marriage is not registered in the civil registration, it can affect the child's status. These are the objectives of why the marriage must be registered: ${ }^{9}$

1. "Good administration of marriage;

2. To give a certainty and protection to the husband, wife and also the child; and

3. To give a guarantee and protection to the certain rights which arises from a marriage such as inheritance rights, rights to obtain a birth certificate, et cetera".

The Constitutional Court extended the substance of Article 43 (1) Law Number 1 of 1974 by its Decision dated February 17, 2012 Number 46/PUU-VIII/2010. Consequently, the paragraph must be read: "A child who is born out of a wedlock has a civil relationship with his/her mother and the mother's family and also with the man who is his/her father, who 
can be proved based on science and technology and/or other proofs according to the law, has a blood relationship, including civil relationship with his/her father's family." 10

Before the Constitutional Court Decision was established, illegitimate children can build their relationship with their father by the child recognition or legitimation. Initially the child recognition and legitimation were regulated in the Dutch Civil Code. The Marriage Law does not regulate such matters. Yet, the Law Number 23 of 2006 regarding Citizenship Administration (hereafter mentioned as "Law 23/2006") stipulates the child recognition and legitimation in Article 49 and 50. The provisions of Article 49 of Law 23/2006:

(1) "The child recognition shall be reported by the parents to the Executant Institution at the latest 30 (thirty) days since the Recognition Letter made by the father and approved by the mother of the respective child.

(2) The reporting obligation as designated in paragraph (1) is excluded for the parents whose religion does not justify a Child Recognition for a child who was born out of wedlock..."

The contents of Article 50 are as follows:

(1) "Every Child Legitimation shall be reported by the parents to the Executant Institution at the latest 30 (thirty) days since the parents of the respective child get married and get the marriage certificate.

(2) The reporting obligation as designated on paragraph (1) is excluded for the parents whose religion does not justify a Child Legitimation for a child who was born out of wedlock..."

The Law 23/2006 is amended by the Law Number 24 of 2013. Some of the Articles were amended including paragraph 2 of Article 49 and 50. The provision of Article 49 (2) becomes: "A Child Recognition only prevails for a child whose parents have married legitimately according to the religion law, yet have not been recognized according to the national law." Furthermore, the provision of Article 50 (2) was amended to: "A Child Legitimation only prevails for a child whose parents have married legitimately according to the religion and national law." 
It is quite a paradox that after the Constitutional Court Decision dated February 17, 2012, determining that a child who is born out of a wedlock has a civil relationship with the man who is his/her father (including with the family), to the extent that the said child can be proved based on science and technology and/or other proofs according to the law and has a blood relationship with the man, while the regulator amended the Citizenship Administration Law in 2013, which regulates that even in the child recognition, the parents shall get married according to the religion law. It may be interpreted that there cannot be child recognition from a man who does not marry the mother's child in accordance with the religion law. The inconsistent stipulations of an out of wedlock can cause law uncertainty and injustice for a child, whether born in wedlock or out of wedlock. Therefore, such rights can be reviewed from the human rights and justice principle.

\section{Children's Civil Rights According to the Human Rights Law}

Human rights are regulated in the Indonesian Constitution which is Undang-Undang Dasar 1945 (UUD 1945) and its Amendments. Such rights are the consequences due to the second principle of Pancasila, which is the nation-wide principle of Indonesia. ${ }^{11}$ The moral principle is the just and civilized human rights. ${ }^{12}$ Humanity values become the base of the human rights. Consequently, a civilized nation must honor the human rights. ${ }^{13}$

The Children's Human Rights are stipulated in Article 28B paragraph (2) of the fourth amendment of the Indonesian Constitution. Every child has a right to live, grow, and thrive, and also has a right to get protection from violence and discrimination. Besides, the child's rights are also stipulated in Law Number 39 of 1999 regarding Human Rights, in Article 52 to Article 66. Article 52 of the Law stipulates that every child reserves a right to a protection by the parents, family, society, and the country. Such child's rights are human rights, and they are recognized and protected since the child is in the womb of the mother. The child's rights are also legislated in Article 4 Law Number 23 of 2002 regarding Child Protection.

The United Nation also pays a thorough attention to children's rights. In November 20, 1989, a convention regarding the child's rights was approved by some of the United Nations members. Indonesia determined to enter the ratification process through the Presidential Decree number 
36 of $1996 \cdot{ }^{14}$ In Article 49 (2) of the Decree, it is stipulated that the Child's Rights Convention prevailed since October 5, 1990. As the consequences of the ratification, Indonesia must obey the Convention as stipulated in article 2:

1. "States parties shall respect and ensure the rights set forth in the present Convention to each child within their jurisdiction within discrimination of any kind, irrespective of the child's or his or her parent's or legal guardian's race, color, sex, language, religion, political, or other opinion, national, ethnic, or social origin, property, disability, or other status.

2. States Parties shall take all appropriate measures to ensure that the child is protected against all forms of discrimination or punishment on the basis of the status, activities, expressed opinions, or beliefs of the child's parents, legal guardians, or family members."

Regarding the civil rights, article 18 (1) of the Convention regulates "States Parties shall use their best efforts to ensure recognition of the principle that both parents have common responsibilities for the upbringing and development of the child. Parents or, as the case may be, legal guardians, have the primary responsibility for the upbringing and development of the child. The best interests of the child will be their basic concern." Furthermore, pursuant to Article 19 (1) the States Parties shall take all appropriate legislative, administrative, social and educational measures to protect the child from all forms of physical or mental violence, injury or abuse, neglect or negligent treatment, maltreatment or exploitation, including sexual abuse, while in the care of parent(s), legal guardian(s) or any other person who has the care of the child. Article 27 (2) clearly stipulates that States Parties recognize the right of every child to a standard of living adequate for the child's physical, mental, spiritual, moral and social development, while in paragraph (2), the obligation of the parents or others responsible for the child to secure, within their abilities and financial capacities, the conditions of living necessary for the child's development. 


\section{Justice Principle in Children's Rights in Civil Law Field}

The issue of injustice regarding Children' Rights in Private Law field arouse when a mother submitted a lawsuit to the Constitutional Court regarding her child's civil rights in 2010. The mother of the child married the father according to the Islamic Law, but such marriage was not registered by the Civil Registration. ${ }^{15}$ Based on the Marriage Law, Article 2 paragraph (1), a lawful marriage is a marriage which is done according to the parties' religion and belief. Moreover, on the paragraph (2), it states that "every marriage is registered according to the prevailing law." The conclusion is, in order to be a lawful marriage, it needs to be registered. The legal consequence of an unregistered marriage is that the child from unregistered marriage cannot be deemed as legitimate child of the father, and the child will only have a civil relationship with the mother as regulated. ${ }^{16}$

In the abovementioned case, the legal bases which were used by the plaintiff are Article 28B paragraph (2) and 28D paragraph (1) of the Constitution. The plaintiff deemed that her child's constitutional rights are violated by the Law Number 1 of 1974 regarding Marriage. As explained above, the contents of Article 43 are: ${ }^{17}$

(1) "A child who is born out of wedlock has a civil relationship with his/her mother and the mother's family.

(2) The child's status as stipulated on paragraph (1) furthermore will be regulated in the government regulation."

The plaintiff stated that the above provisions violate Article 28B paragraph (2) of the Constitution that determines "every child reserves a right to live, grow, and thrive, and also reserves a right to get protection from violence and discrimination." The next article which is violated is Article 28D paragraph (1) that states "every person reserves a right upon acknowledgment, guarantee, protection, and just legal certainty and equal treatment before the law." ${ }^{\prime 18}$

The government gave plea regarding the plaintiff's petition. The plea included Article 28J paragraph (1) which explains that every person shall respect other person's human rights in the order of society, nation, and country's life. Moreover, paragraph (2) of the same article states that in implementing one's right and freedom, every person shall obey the 
limitations which are regulated by the laws merely in order to ensure the acknowledgement and the honor upon other people's rights and freedom and for fulfilling the fair requirement in accordance with the moral, religion values, security, and public order in a democratic society. ${ }^{19}$ Such stipulation derogates freedom, but the purposes are for the nation's and society's best interest, to avoid the violation of one's constitutional right by the implementation of other person(s)' rights.

One can conclude that Indonesian Constitution regulating one's right and freedom is limited by other people's right and freedom. On the other side, there are human rights, which in this case child's human rights, that must be applied based on equal treatment to a child. The question is: Is it just if a legitimate child and illegitimate child have the same rights in civil law field?

Philosophers such as Plato and Aristotle believe that justice is the soul of legal thought. ${ }^{20}$ Plato believes that the objective of a country is to uphold justice, therefore law and justice have a central position. ${ }^{21} \mathrm{His}$ apprentice, Aristotle, emphasizes the importance of polis in one's life. He has an understanding that law and ideal constitution hold a significant portion to put the society well ordered. ${ }^{22}$ According to him, a just law is law that takes sides to all people's interest. It has to defend the common interest and the common good. ${ }^{23} \mathrm{~A}$ just constitution becomes important because a country as one unity consists of free and equal individuals, while each individual has different interests compared to other. ${ }^{24}$ Therefore, a constitution accommodates all parties' interest fairly and justly. ${ }^{25}$ By fair and just constitution, human can reach happiness (eudaimonia) which is the main purpose of human's life. ${ }^{26}$ The importance of the constitution for common good is also proclaimed by Rawls. ${ }^{27}$ Citizen's rights and freedom must be applied under constitution. It means that in the public domain, a measurement which should be used to judge society members' behavior is the Constitution, because the Constitution basically contains citizen's rights and obligations, including das sollen rights and obligations of a country to the citizens. ${ }^{28}$

Indonesia is a country that holds community values such as moral and religious values. Devlin has a viewpoint that public morality is important. ${ }^{29}$ Yet the questions are how it will be determined as a public morality and who will determine it. Based on Devlin's opinion, public morality is determined by certain people who are called "the right minded men", the 
people who direct their life with the conscience about what is right and what is wrong. ${ }^{30}$ The said people, who care for the public interest, and therefore bear the responsibility to make laws, are the legislators. Such opinion comes from Thomas Aquinas, complemented by Devlin who states that the legislators work with the sensitivity guidance to measure what is right and what is wrong, what is fair and not fair pursuant to the society's point of view, then make such point of view into norm form which becomes the public morality. ${ }^{31}$

Public morality is needed to be the guiding principles, especially in pluralistic society. ${ }^{32}$ It will become useful in handling interests' conflict, although usually problems are solved based on issue-by-issue principle. ${ }^{33}$ Regarding the basic and guiding principles, a society should be directed by an ideology as an ideal and vision. In Indonesia, such basic and guiding role is realized in Pancasila. ${ }^{34}$ As the ideology of Indonesia, Pancasila contains the nation's principles which become not only the face of Indonesia, but also the inspiration pertaining how such ideal image is embodied. Consequently, Pancasila becomes the "values frame" for the Indonesian to review the journey and achievement of their country. ${ }^{35}$ Pancasila is also the roof of law ideal or "cita bukum" in Indonesia. ${ }^{36}$ It is established by the founders as the philosophical foundation in arranging the frame and the basic structure of the country's bodies as stipulated in the constitution. ${ }^{37}$

Pancasila as the guiding principle must also be applied in civil law field. Abdulkadir Muhammad expresses Indonesian Civil Law must be in accordance to Pancasila values culture. ${ }^{38}$ Those values are the concepts of the laws which live in most of the mindsets of Indonesians. ${ }^{39}$ Such culture strongly permeates the souls of Indonesian people, and is difficult to be replaced by other values culture in a short term. ${ }^{40}$ Abdulkadir states that to classify whether a law is an Indonesian Civil Law can be done by reviewing the law using Pancasila as the foundation. ${ }^{41}$ If such law is sourced, guided, or in accordance to Pancasila, it can be classified as Indonesian Civil Law. ${ }^{42}$

Based on the above explanation, one can measure whether a norm is just or unjust by using the guiding principles which are Pancasila and the Constitution. First, I would like to discuss about Pancasila. John Gardner, an American intellectual and politician, said that "no nation can achieve greatness unless it believes in something, and unless that something has moral dimensions to sustain a great civilization." ${ }^{43}$ Pancasila has strong ontological, epistemological, and axiological base as the moral foundation 
and the nation's course. ${ }^{44}$ Discussing justice according to Pancasila means that one looks at the second and the fifth moral principles.

The second moral principle is "Just and civilized humanity". This moral principle refers to the basic human values which are concreted in human rights, a proper living standard as human being, and also a fair and democratic governmental system. ${ }^{45}$ Humane values are the base of what now are called human rights. ${ }^{46}$ Yet, it must be considered that the foundation of the second moral principle is the first moral principle, that is, "Belief in the one and only God". ${ }^{47}$ The second moral principle is the concrete implementation and the living practice of the first principle. ${ }^{48}$ In the moral principle order of Pancasila, the first principle cannot be separated from the other principles. The difference between the two principles is that the first principle emphasizes the vertical relation, while the second principle focuses on the horizontal relation. ${ }^{49}$

As an implementation of the second moral principle, Indonesia regulates human rights, including child's human rights, in the constitution and Law Number 39 of 1999 regarding Human Rights. The following are some principles of Law Number 39, 1999. ${ }^{50}$

1. Indonesia's commitment to uphold human rights and human freedom (Article 2);

2. Non-discrimination principle (Article 3 and 5);

3. Protection guarantee for the non-derogable rights (Article 4), such as the right to live, the right not be tortured, the right for private mind and conscience freedom, the right to have a religion, the right not to be enslaved, the right to be admitted as a person, the equality before the law, and the right not to be prosecuted based on retroactive law.

In human rights, there are derogable and non-derogable rights. Derogable rights are rights that can be limited. On the other hand, there are non-derogable rights that cannot be derogated. It means they must be respected and cannot be limited. The child's rights which are stipulated in the constitution and the prevailing laws are not non-derogable rights. Such rights can be limited. The reason of the limitation is actually stated in Article 28J of the constitution: "in implementing one's right and freedom, every person shall obey the limitations which are regulated by the laws 
merely in order to ensure the acknowledgement and the honor upon other people's rights and freedom and for fulfilling the fair requirement in accordance with the moral, religion values, security, and public order in a democratic society."

The implementation of one's rights must obey the law. According to Devlin, the people who determine public morality and who claim what is right and what is wrong, are the "right minded men". They are called the legislators. ${ }^{51}$ However, a prevailing law can be legal yet illegitimate because it does not express the sense of justice in the society. ${ }^{52}$ Regarding marriage, legislators established Law Number 1 of 1974. In this law, legislators differentiate the status of a child to a legitimate and illegitimate child. The status of a child affects the rights. Some people consider difference of the rights as injustice because non-discriminative is one of the human rights' principles. At the same time, other people have different opinion by agreeing to such difference of rights.

Sudikno Mertokusumo claims that it is difficult to put limit to fairness substance. ${ }^{53} \mathrm{He}$ explains further using Aristotle's justice theory. Aristotle divides justice into two kinds: distributive justice and commutative justice. ${ }^{54}$ Distributive justice is justice that gives rights to each person according to his/her portion or summ cuique tribuere ("to each his own"). ${ }^{55}$ The portion is not the same for each person because it depends on the wealth, birth, education, ability, and other aspects. ${ }^{56}$ What is just in this kind of justice is based on the proportionality. ${ }^{57}$ To determine the distributive justice is the legislators' task. ${ }^{58}$ Each person has a right in accordance to the person's service or competence. ${ }^{59}$ What is required is proportionality, not equality. Equality is the focus of commutative justice. In this kind of justice, each person gets the same portion, and to apply commutative justice is the judge's task. ${ }^{60}$

The government stated that limitation of the rights as regulated in Article 28J paragraph (2) of the constitution is the "logic consequence" of the country's obligation mandated in the constitution préambule, “...to establish Indonesia country government that protects the entire nation, and the whole Indonesia homeland, to bring forward the public welfare, to educate the nation life...". ${ }^{61}$ It means that in the event of constitutional rights limitation existed in a norm, in fact the limitation is the country's effort to reach the country's objectives as mandated in the préambule of the 
constitution. In this case, one can conclude that the country through the legislators try to implement the distributive justice in Marriage Law.

The rights for child are different due to the fulfillment of law procedures, and such procedures are established to accommodate the moral, religion values, and also public order in the democratic society. The law is used as the tool for social engineering, to shape the society as it wants. ${ }^{62}$ And the law must be sourced from the grundnorm which is Pancasila and the Constitution, UUD 1945 and its amendment. Yet, the law still provides a mechanism for a child to fix his/her civil relationship with the biological parents with the Law 23/2006 that has been changed in the Law 24/2013 regarding Citizenship Administration. The mechanisms are about child recognition or child legitimation.

\section{Conclusion}

According to the prevailing laws, child's civil rights are determined by the status of the said child whether he/she is a legitimate or illegitimate child. Such status is obtained by meeting the law substance in marriage law and the procedures in administrative law. The problem appeared when there was a mother who sought justice to the Constitutional Court for his son considered as illegitimate child due to unregistered marriage. She claimed that her son's constitutional rights are violated because he is not treated equally as other legitimate child.

In its decision regarding the aforementioned case, the Constitutional Court extended the substance of Article 43 (1) Law Number 1 of 1974. Hence, it must be read: "A child who is born out of wedlock has a civil relationship with his/her mother and the mother's family and also with the man who is his/her father, who can be proved based on science and technology and/or other proofs according to the law, has a blood relationship, including civil relationship with his/her father's family." It can be interpreted that the rights of legitimate and illegitimate children are the same. The question is, "Is it just?"

To determine what is just and unjust, we have to review it according to some aspects. The first aspect is from the guiding set of principles which in Indonesia is Pancasila. Pancasila as the cornerstone of the nation states in its second moral principle "the just and civilized humanity". 
Such principle is realized in human rights, including the children's human rights. The second aspect to determine what is just and unjust is the Constitution. Rawls expresses that the citizen's rights and freedom must be executed under a constitution. It means that in the public domain a measurement which should be used to judge the society members' behavior is the Constitution, because the Constitution basically contains the citizen's rights and obligations. Based on Article 28J paragraph (2), some human rights can be limited due to certain considerations, such as the moral, religion values, security, and public order. The last aspect to review with is Aristotle's justice theory, which divides justice to distributive and commutative justice. In assuring child's civil rights, distributive justice is implemented. A legitimate child will have the full civil rights from both parents, while an illegitimate child will have the civil rights from the mother's side.

\section{Bibliography}

Badan Perencanaan dan Pengembangan Daerah Kabupaten Kendal. Konvensi Hak-Hak Anak (KHA), http://bappeda.kendalkab. go.id/info-terkini/87-konvensi-hak-hak-anak-kha.html (access 06.09.2016).

Kusumohamidjojo, Budiono. Filsafat Hukum: Problematik Ketertiban yang Adil. Jakarta: Gramedia Widiasarana Indonesia (Grasindo), 2004.

Latif, Yudi. Negara Paripurna: Historisitas, Rasionalitas, dan Aktualitas Pancasila. Jakarta: Gramedia Pustaka Utama, 2012.

Meliala, Djaja S. Perkembangan Hukum Perdata Tentang Orang dan Keluarga. Bandung: Nuansa Aulia, 2015.

Mertokusumo, Sudikno. Mengenal Hukum. Yogyakarta: Liberty, 1999.

Muhammad, Abdulkadir. Hukum Perdata Indonesia. Bandung: PT Citra Aditya Bakti, 2010.

Rahardjo, Satjipto. Ilmu Hukum. Bandung: PT Citra Aditya Bakti, 2012.

Sidharta, Arief. Ilmu Hukum Indonesia Upaya Pengembangan Ilmu Hukum yang Responsif terhadap Perubahan Masyarakat. Bandung: Unpar Press, 2016 
Smith, Rhona K. M., Asplund, Knut D., \& Marzuki, Suparman. Hukum Hak Asasi Manusia. Yogyakarta: PUSHAM Universitas Islam Indonesia, 2008.

Subekti, Raden \& Tjitrosudibio, Raden. Kitab Undang-Undang Hukum Perdata. Jakarta: PT Pradnya Paramita, 1992.

Ujan, Andre Ata. Filsafat Hukum Membangun Hukum Membela Keadilan. Yogyakarta: Penerbit Kanisius, 2009.

Laws

The Constitution of the Republic of Indonesia and its amendments.

Indonesia, Marriage Law, Law Number 1 of 1974, State Gazette of the Republic of Indonesia Number 1 of 1974.

Indonesia, Child Protection Law, Law Number 23 of 2002, State Gazette of the Republic of Indonesia Number 109 of 2002.

Indonesia, Citizenship Administration Law, Law Number 23 of 2006 , State Gazette of the Republic of Indonesia Number 124 of 2006.

Indonesia, Amendment of Citizenship Administration Law, Law Number 24 of 2013, State Gazette of the Republic of Indonesia Number 232 of 2013.

Constitutional Court Decision Number: 46/PUU-VII/2010 dated February 17, 2012.

Convention on the Rights of the Child dated 20 November 1989.

\section{Endnotes:}

1 Lecturer at Faculty of Law, Parahyangan Catholic University, Bandung, email: wurianalya_mari@yahoo.com.

2 Abdulkadir Muhammad, Hukum Perdata Indonesia (Bandung: PT Citra Aditya Bakti, 2010), 6

3 Ibid.

4 Ibid., 7.

5 Djaja S.Meliala, Perkembangan Hukum Perdata Tentang Orang dan Keluarga (Bandung: Nuansa Aulia, 2015 ), 72.

6 Ibid., 72-73.

Ibid., 75 .

$8 \quad$ Ibid. 76.

9 Constitutional Court Decision Number: 46/PUU-VII/2010 dated February 17, 2012

10 Ibid. 
1 Yudi Latif, Negara Paripurna Historisitas Rasionalitas Aktualitas Pancasila (Jakarta: PT Gramedia, 2012), 243.

12 Ibid.

13 Ibid.

14 Badan Perencanaan dan Pengembangan Daerah Kabupaten Kendal, Konvensi HakHak. Anak (KHA), http://bappeda.kendalkab.go.id/info-terkini/87-konvensi-hakHak Anak (KHA), http://bappeda.ke
hak-anak-kha.html (access 06.09.2016)

15 Constitutional Court Decree Number: 46/PUU-VII/2010.

16 Ibid.

17 Ibid.

18 Ibid.

19 Ibid.

20 Andre Ata Ujan, Filsafat Hukum Membangun Hukum Membela Keadilan (Yogyakarta: Penerbit Kanisius, 2009), 37.

21 Ibid., 39.

22 Ibid.

23 Ibid., 40 .

24 Ibid.

25 Ibid.

26 Ibid., 39.

27 Ibid., 149.

28 Ibid.

29 Ibid., 146

30 Ibid.

31 Ibid.

32 Ibid., 147

33 Ibid.

34 Ibid., 148 .

35 Ibid.

36 Arief Sidharta, Imu Hukum Indonesia Upaya pengembangan Ilmu Hukum yang responsif terbadap perubahan masyarakat (Bandung: Unpar Press, 2016), 147.

37 Ibid.

38 Abdulkadir Muhammad., op.cit., 11.

39 Ibid.

40 Ibid.

41 Ibid.

42 Ibid.

43 Yudi Latif, op.cit., 42.

44 Ibid.

45 Ibid., 243.

46 Ibid.

47 Ibid. 


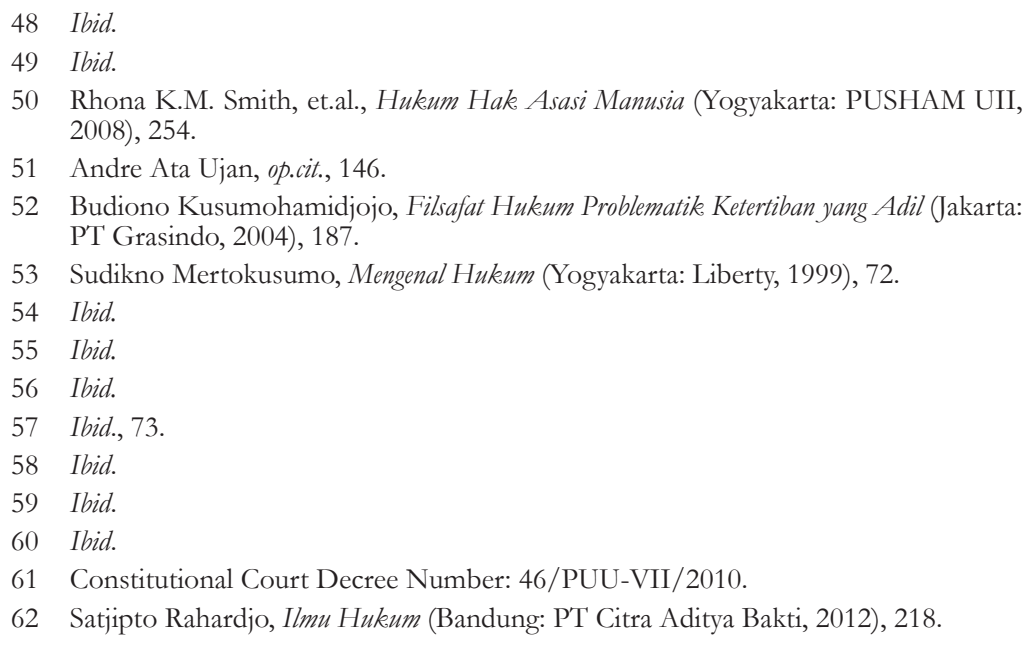

